\title{
Müsabaka Öncesi Elit Yıldız Greko-Romen Güreşçilerin Öz Güven Düzeylerinin Çeşitli Değişkenler Açısından İncelenmesi ${ }^{1}$
}

\author{
DOI: $10.26466 /$ opus.563554 \\ * \\ İlimdar Yalçın* - Cihan Ayhan ${ }^{* *}$ - Abdullah Düğenci ${ }^{* * *}$
}

* Dr. Öğr. Üyesi, Bingöl Üniversitesi, Beden Eğitimi ve Spor Yüksekokulu, Bingöl / Türkiye

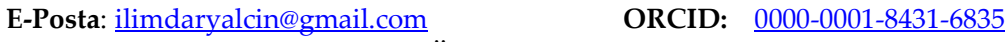

** Arş. Gör., Sakarya Uygulamalı Bilimler Üniversitesi, Spor Bilimleri Fakültesi, Sakarya / Türkiye

E-Posta: cihanayhan@subu.edu.tr ORCID: 0000-0002-7633-1389

*** Arş. Gör., Sakarya Uygulamalı Bilimler Üniversitesi, Spor Bilimleri Fakültesi, Sakarya / Türkiye

E-Posta: adugenci@subu.edu.tr ORCID: $\quad$ 0000-0002-3608-4715

\section{Öz}

Bu çalışmanın amacl, elit yıldız greko-romen güreşçilerin müsabaka öncesi öz güven düzeylerini çeşitli değişkenler açısından incelemektir. Araştırma grubunu, Yıldızlar Greko-Romen Güreş Türkiye Şampi-

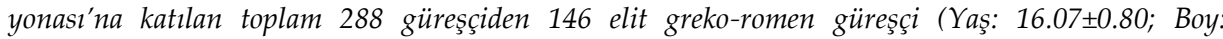

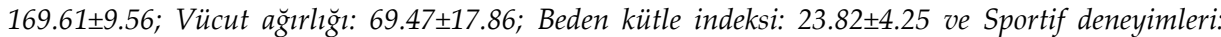
4.73 \pm 1.67 ) oluşturmaktadır. Araştırmada demografik değişkenlerin yanı sıra, Akın (2007) tarafindan geliştirilen "Öz Güven Ölçeği" kullanılmıştır. Ölçek, iki alt boyutan (iç ve dış öz güven) oluşmaktadır. Araştırmada elde edilen verilerin analizinde SPSS paket programı kullanılmıştır. Verilen normallik sınaması Kolmogorov-Smirnov testi ile analiz edilmiştir. Normal dağılım gösteren verilerin analizinde ikiden fazla grubun karşılaştırmasında One-Way ANOVA kullanılmıştır. Araştırma bulgularına göre, yaş grupları, beden kütle indeksi grupları, kaybedilen ă̆ırlık yüzde sınıflandırması, yıl içinde kilo düşme sayıları ve başarı düzeyi sinıflandırmalarn ile içsel ve dışsal öz güven düzeyleri arasında istatistiksel açıdan anlamlı farklılık olmadı ̆̆g tespit edilmiştir ( $p>, 05)$. Sonuç olarak, elit yıldız greko-romen güreşçilerin içsel (Ortalama=3,77) ve dişsal öz güven (Ortalama=3,76) düzeylerinin yüksek olduğ u tespit edilmiştir. Bu sonuç, sporcuların müsabaka öncesi ağırlık kaybı gerçekleştirmelerine rağmen öz güven düzeylerinde herhangi bir farklılık olmadığı göstermektedir.

Anahtar Kelimeler: Ağırlık Kaybı, Greko-Romen Güreş, Yıldız Sporcular, Öz Güven

\footnotetext{
${ }^{1}$ Bu çalışma 28 Haziran - 1 Temmuz 2018 tarihleri arasında istanbul'da düzenlenen ERPA Uluslararası Eğitim Kongresi'nde sözel bildiri olarak sunulmuştur
} 


\title{
Investigation of Self-Confidence Levels of Elite Cadet Greco-Roman Wrestlers before the Competition According to Various Variables
}

\begin{abstract}
The aim of the present study was to investigations of self-confidence levels of elite cadet Greco-Roman wrestlers before the competition according to various variables. The present study's population was consisted of 288 wrestlers and samples was consisted 146 elite Greco-Roman wrestlers (age: $16.07 \pm$ 0.80, height: $169.61 \pm 9.56$, body weight: $69.47 \pm 17.86$, body mass index: $23.82 \pm 4.25$ and sports experience: $4.73 \pm 1.67)$. In addition to the demographic variables, "Self-confidence scale" developed by Akin (2007) was used in the research. The scale consisted of a summary score (general self-confidence) and two subscale (internal and external self-confidence). The normality test of the obtained data was analyzed by the Kolmogorov-Smirnov test. In the analysis of the obtained data, one-way ANOVA was used for comparisons of more than two groups. According to the research results, it was determined that there was no statistically significant difference in terms of the age groups, classification of body mass index, percentage of weight loss classification, number of weight loss during the year and classification of success level in the internal and external self-confidence levels of cadet wrestlers. As a result, the elite cadet Greco-Roman wrestlers were found to have high levels of internal (Mean=3,77) and external selfconfidence (Mean=3,76). This result has shown that there is no difference in self-confidence levels although the wrestlers lose weight pre-competition.
\end{abstract}

Keywords: Weight Loss, Greko-Romen Wrestling, Cadet Athletes, Self-Confidence 


\section{Giriş}

Kendine güvenmek, kendine değer vermeyi gerekli kılar. Birey, kendini fiziksel ve psikolojik kusurlarına, başarısızlıklarına ve olumsuzluklarına rağmen sevmelidir (Mutluer, 2006). Bireyin kendisinden hoşnut olması ancak bireyin kendisini tanımasıyla mümkün olabilir. Kendini tanıyıp kendi ilkeleri doğrultusunda kendisini geliştirebilen kişi, kendi karakterini inşa edebilecektir. Birey kendi karakterini geliştiremediği ve ortaya koyamadığı zaman ne kendisiyle ne de çevresiyle sağlıklı ilişkiler kuramaz (Cüceloglu, 2003). Bireyin, hem kendisi ile hem de çevresindekilerle olumlu ilişkiler kurmasını sağlayan en önemli faktörden birisi de öz güvendir.

Öz güven, psikolojik yönden basit bir özellik olarak görülse de değişkendir ve başka birçok özellikle bağlantıları vardır. Ayrıca öz güven doğuştan kazanılan bir özellik değildir, çocukluktan itibaren kademe kademe gelişen merkezi bir özelliktir. Yaşam boyunca karşılaşılan düş kırıklıkları ve ruhsal zedelenmeler sistematik olarak insanın öz güvenini olumsuz yönde etkiler. Yaşam boyu ne kadar çok düş kırıklığı yaşarsa, kişinin öz güveni de o derece azalır, korkularıysa çoğalır. Dolayısıyla öz güven kavramı iyimserlik ve karamsarlıkla sıkı bir ilişki içerisindedir (Merey, 2010). Öz güven sahibi olan kişilerin kilit unsuru, yüksek öz saygılarının olmasıdır. Kendilerini pozitif öz saygı içinde tutarlar. Bu durum, kendilerini nasıl seveceğini bildikleri ve hangi konularda iyi olduklarının farkında oldukları anlamına gelmektedir. Bu farkındalıklar, daha fazla zorlukla başa çkabilme kabiliyetlerini ve esnekliklerini artırır (Burton ve Platts, 2017).

Öz güvene sahip olan birey kendini iyi hisettiği dünyası içinde daha üretken, yaratıcı ve verimlidir. Benliğini daha iyi tanıdığından neye gücünün yetip yetmeyeceğinin, neleri yapıp yapamayacağının bilinci ile hedeflerini ona göre belirlediklerinden, mücadelelerini sürdürmede başarılıdır. Sorunlardan kaçmaz, bunlarla yüzleşerek sorunların olduğundan daha büyük görünmesine izin vermez. Görev ve sinırlarının ne olduğunun bilinci ile yaptığ Bağımsız birey olarak karar verme ve tercih etme hakkı kendisine aittir (Göknar, 2007). Ayrıca hayat mücadelesinde insanın herhangi bir zorlukla mücadele edebilme gücünü sağlamasında öz güven son derece önemli bir 
konumda olup, insana mücadele azmi sağlayarak başarılı olma arzusuna yatkınlık sağlar. Dahası çevremizdeki unsurlara bağlı olarak artabilir veya azalabilir. Önemli olan bu süreci dengeli bir şekilde muhafaza etmek ve sürdürebilmektir (Çetinkaya, 2015).

Öz güven, çeşitli spor dallarında büyük öneme sahiptir. Bu spor dallarından bireysel bir spor branşı olan güreş sporcularında öz güven düzeyi daha çok öneme sahiptir. Güreşçilerin öz güven düzeylerini sporcuların yıl içerisinde kaybettikleri kilo kaybı seviyesi, müsabakalarda kazandıkları başarılar ve çevresel faktörler gibi değişkenlerin etkilediği düşünülmektedir.

Güreşçilerim müsabaka öncesi ağırlık kaybı gerçekleştirmelerinin en temel nedenlerinden biri de bir alt sıklette yarışmanın onlara pozitif katkı sağlayacağı ve bir alt sıklette madalya şansının daha yüksek olduğu psikolojisine sahip olmalarıdır. Ancak literatürde ağırlık kaybı ile ilgili yapılan çalışmalar genellikle dehidrasyonun sporcuların fizyolojik maksimallerinde düşüşe sebep verdiği yönündedir (Maughan ve Shirreffs, 2008; Kukidome vd., 2008; Hayes ve Morse, 2010, Işık ve Cicioğlu, 2016).Yine müsabaka öncesi ağırlık kaybı gerçekleştiren sporcuların hidrasyon durumlarında değişiklik gerçekleştiği gibi besin ve sıvı kısıtlamasına bağlı olarak; uyku bozukluğu, öğrenme, hafıza, anksiyete, depresyon, beden ısısı düzensizliği ve kas fonksiyon bozuklukları gibi belirtilerin görülebileceği bildirilmiştir (Işık vd., 2013). Bu bilgiler kapsamında bu araştırmanın amacı, elit yıldız greko-romen güreşçilerin müsabaka öncesi öz güven düzeylerini çeşitli değişkenler açısından incelemektir.

\section{Yöntem}

Bu bölümde, araştırma grubu, veri toplama aracının özellikleri, verilerin çözümlenmesi ve bulguların elde edilmesinde kullanılan istatistiksel çözümleme teknikleri hakkında bilgi verilmiştir.

\section{Araştırma Grubu}

Araştırma grubunu, Yıldızlar Greko-Romen Güreş Türkiye Şampiyonası'na katılan toplam 288 güreşçiden 146 elit yıldız greko-romen güreşçi

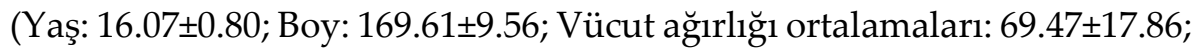


Beden kütle indeksi ortalamaları: $23.82 \pm 4.25$ ve Sportif deneyimleri: $4.73 \pm 1.67$ ) oluşturmuştur.

\section{Veri Toplama Araçları}

Öz güven ölçeği Türkçe olarak Akın (2007) tarafından geliştirilmiştir. Öz güven ölçeği iç öz güven (17 madde) ve dış öz güven (16 madde) olmak üzere 2 alt boyut ve 33 maddeden oluşmaktadır. Ölçek 5'li likert (1=Hiçbir zaman ........ 5=Her zaman) tipindedir. Ölçek için genel Cronbach's alpha .83 olarak belirlenmiştir. Alt boyutlar incelendiğinde, iç öz güven için Cronbach's alpha .83 ve diş öz güven için .85 olarak tespit edilmiştir. Mevcut araştırma için öz güven ölçeği toplam Cronbach's alpha değeri 0.89 , iç öz güven için 0.87 ve dış öz güven için ise 0.76 olarak tespit edilmiştir.

\section{Beden Kütle İndeksi Hesaplaması}

BKİ = Ağırlık (kg)/boy uzunluğu (m)² formülü ile hesaplanmıştır. BKİ değerlendirmeleri Dünya Sağlık Örgütü verilerine dayalı yapılmıştır. Bu bağlamda;

$18,5 \mathrm{~kg} / \mathrm{m}$.'nin altında olanlar: Zayıf

$18.5-24,9 \mathrm{~kg} / \mathrm{m}$. arasinda olanlar: Normal

$25-29,9 \mathrm{~kg} / \mathrm{m}$. arasında olanlar: Şişman

$30-39,9 \mathrm{~kg} / \mathrm{m}$. arasında olanlar: Obez olarak gruplandırılmıştır (Who, 2004).

\section{Kaybedilen Ağırlık Yüzdesi Hesaplaması}

Sporcular'a demografik değişken olarak, "Gerçek vücut ağırlığınız nedir?" ve "Müsabaka sıkletiniz nedir?" sorulmuştur. Sporcuların vermiş oldukları cevaplara göre kaybedilen ağırlık yüzdeleri \% $\Delta=$ [ (Müsabaka sıkleti - Gerçek vücut ağırlığı)/ Gerçek vücut ağırlığı]×100 formülü ile hesaplanmış ve kaybedilen ağırlık yüzdesi olarak kaydedilmiştir (Yagmur vd., 2019). Dahası, Casa ve diğerleri (2000), egzersiz sonucu oluşan dehidrasyonu \%1'lik dehidrasyon uygun dehidrasyon, $\%>1-3$ 'lik dehidrasyonu hafif dehidrasyon, $\%>3-5$ 'lik dehidrasyonu yüksek dehidrasyon ve $\%>5$ 
ve üzeri dehidrasyonu aşırı dehidrasyon olarak sınıflandırdığı tespit edilmiştir. Çalışmamızda da kaybedilen ağırlık yüzdesi sınıflandırmaları yukarıdaki kriterler göz önünde bulundurularak yapılmıştır.

\section{Verilerin Analizi}

Araştırmada elde edilen veriler için SPSS paket programından faydalanılmış ve değişkenlerin frekans (f) ve yüzde (\%) dağılımları hesaplanmıştır. Verilerin normallik sınaması Kolmogorov-Smirnov testi ile analiz edilmiştir (Tablo 1). Normal dağılım gösteren verilerin analizinde ikiden fazla grubun karşılaştırmalarında One-Way ANOVA testi kullanılmıştır. Araştırmada hata payı $\mathrm{p}<0,5$ olarak alınmıştır.

Tablo 1. Verilerin Normallik Stnaması Testi

\begin{tabular}{llll}
\hline & \multicolumn{3}{c}{ Kolmogorov-Smirnov } \\
\cline { 2 - 4 } & Statistic & sd & p \\
\hline İç Öz Güven &, 073 & 146 &, 057 \\
\hline D1ş Öz Güven &, 046 & 146 &, 200 \\
\hline
\end{tabular}

\section{Bulgular}

Bu bölümde araştırmaya katılan sporcuların yaş grupları, beden kütle indeksi grupları, kaybedilen ağırlık yüzde sınıflandırması, yıl içinde kilo düşme sayıları ve başarı düzeyi sınıflandırılmaları ile içsel ve dışsal öz güven düzeyleri arasında istatistiksel açıdan anlamlı farklılık olup olmadığını ilişkin analiz sonuçları verilmiştir.

Tablo 2. Katılımcıların Yaş Değişkenine Göre Öz Güven Alt Boyutları ANOVA Sonuçları

\begin{tabular}{lllllll}
\hline Değişken & Yaş & $\mathbf{n}$ & $\overline{\mathbf{X}}$ & Ss & $\mathbf{F}$ & $\mathbf{p}$ \\
\hline \multirow{4}{*}{ İç Öz Güven } & 15 & 42 & 3,69 &, 72 & & \\
& 16 & 52 & 3,74 &, 62 & 1,191 &, 307 \\
& 17 & 52 & 3,89 &, 66 & & \\
& Toplam & $\mathbf{1 4 6}$ & $\mathbf{3 , 7 8}$ &, $\mathbf{6 7}$ & & \\
Diş Öz Güven & 15 & 42 & 3,69 &, 70 & & \\
& 16 & 52 & 3,71 &, 79 & \multirow{2}{*}{, 081} & \\
& 17 & 52 & 3,88 &, 66 & & \\
\hline
\end{tabular}


Tablo 2 incelendiğinde, araştırmaya katılan sporcuların yaş değişkeni ile öz güven alt boyutları (iç öz güven, dış öz güven) arasında istatistiksel olarak anlamlı bir fark gözlenmemiştir ( $p>, 05)$.

Tablo 3. Beden Kütle İndeksi Değişkenine Göre Öz Güven Alt Boyutları ANOVA Sonuçları

\begin{tabular}{|c|c|c|c|c|c|c|}
\hline Değişken & $\begin{array}{l}\text { Beden Kütle } \\
\text { Índeksi }\end{array}$ & $\mathbf{n}$ & $\overline{\mathbf{X}}$ & Ss & $\mathbf{F}$ & p \\
\hline \multirow{5}{*}{$\begin{array}{l}\text { İç Öz } \\
\text { Güven }\end{array}$} & Zayıf & 13 & 3,51 & 84 & \multirow{5}{*}{1,036} & \multirow{5}{*}{,378 } \\
\hline & Normal & 83 & 3,78 & 65 & & \\
\hline & Şişman & 35 & 3,78 & 65 & & \\
\hline & Obez & 15 & 3,95 & 62 & & \\
\hline & Toplam & 146 & 3,78 & 67 & & \\
\hline \multirow{5}{*}{$\begin{array}{l}\text { Diş Öz } \\
\text { Güven }\end{array}$} & Zayıf & 13 & 3,37 & 83 & \multirow{5}{*}{1,753} & \multirow{5}{*}{ 159 } \\
\hline & Normal & 83 & 3,80 & ,73 & & \\
\hline & Şişman & 35 & 3,75 & 67 & & \\
\hline & Obez & 15 & 3,94 & 60 & & \\
\hline & Toplam & 146 & 3,77 & 72 & & \\
\hline
\end{tabular}

Tablo 3 incelendiğinde, araştırmaya katılan sporcuların beden kütle indeksi değişkeni ile öz güven alt boyutları (iç öz güven, dış öz güven) arasinda istatistiksel olarak anlamlı bir fark tespit edilmemiştir $(p>, 05)$.

Tablo 4. Kaybedilen Ă̆ırlık Değişkenine Göre Öz Güven Alt Boyutları ANOVA Sonuçları

\begin{tabular}{lllllll}
\hline Değişken & $\begin{array}{l}\text { Kaybedilen Ăğırlık } \\
\text { Yüzdesi }\end{array}$ & $\mathbf{n}$ & $\overline{\mathbf{X}}$ & Ss & $\mathbf{F}$ & $\mathbf{p}$ \\
\hline \multirow{3}{*}{ İç Öz } & Uygun $(\leq 1 \%)$ & 76 & 3,79 &, 66 & & \\
Güven & Hafif $(>1-3 \%)$ & 27 & 3,68 &, 72 & & \\
& Yüksek $(>3-5 \%)$ & 13 & 4,00 &, 50 &, 763 &, 517 \\
& Aşırı $(>5 \%)$ & 30 & 3,73 &, 70 & & \\
& Toplam & $\mathbf{1 4 6}$ & $\mathbf{3 , 7 8}$ &, 67 & & \\
Diş Öz & Uygun $(\leq 1 \%)$ & 76 & 3,74 &, 67 & & \\
Güven & Hafif $(>1-3 \%)$ & 27 & 3,67 &, 71 & & \\
& Yüksek $(>3-5 \%)$ & 13 & 4,25 &, 96 & 2,244 &, 086 \\
& Aşırı $(>5 \%)$ & 30 & 3,70 &, 68 & & \\
& Toplam & $\mathbf{1 4 6}$ & $\mathbf{3 , 7 7}$ & $\mathbf{7 2}$ & & \\
\hline
\end{tabular}


Tablo 4 incelendiğinde, araştırmaya katılan sporcuların kaybedilen ağırlık değişkeni ile öz güven alt boyutları (iç öz güven, dış öz güven) arasında istatistiksel olarak anlamlı bir fark tespit edilmemiştir $(\mathrm{p}>, 05)$.

Tablo 5. Yıl İçerisinde Kilo Düşme Sayısı Değişkenine Göre Öz Güven Alt Boyutları ANOVA Sonuçları

\begin{tabular}{|c|c|c|c|c|c|c|}
\hline Değişken & $\begin{array}{l}\text { Yıl İçerisinde Kilo } \\
\text { Düşme Sayısı }\end{array}$ & $\mathbf{n}$ & $\overline{\mathbf{X}}$ & Ss & $\mathbf{F}$ & $\mathbf{p}$ \\
\hline \multirow{4}{*}{ İç Öz Güven } & Hiç düşmeyen & 52 & 3,84 & 60 & \multirow{4}{*}{,474 } & \multirow{4}{*}{623} \\
\hline & En fazla 2 defa & 59 & 3,72 & ,71 & & \\
\hline & 3 defa ve daha fazla & 35 & 3,78 & 69 & & \\
\hline & Toplam & 146 & 3,78 & ,67 & & \\
\hline \multirow{4}{*}{ Diş Öz Güven } & Hiç düşmeyen & 52 & 3,79 & 61 & \multirow{4}{*}{,053 } & \multirow{4}{*}{,948 } \\
\hline & En fazla 2 defa & 59 & 3,76 & ,84 & & \\
\hline & 3 defa ve daha fazla & 35 & 3,74 & ,66 & & \\
\hline & Toplam & 146 & 3,77 & ,72 & & \\
\hline
\end{tabular}

Tablo 5 incelendiğinde, araştırmaya katılan sporcuların yıl içerisinde kaybettikleri kilo düşme sayısı ile öz güven alt boyutları (iç öz güven, diş öz güven) arasında istatistiksel olarak anlamlı bir fark gözlenmemiştir $(\mathrm{p}>, 05)$.

Tablo 6. Başarı Düzeyi Değişkenine Göre Öz Güven Alt Boyutları ANOVA Sonuçları

\begin{tabular}{lllllll} 
Değişken & Başarı Düzeyi & $\mathbf{n}$ & $\overline{\mathbf{X}}$ & Ss & $\mathbf{F}$ & $\mathbf{p}$ \\
\hline \multirow{4}{*}{ İç Öz Güven } & Yok & 49 & 3,86 &, 63 & & \\
& Ulusal & 75 & 3,72 &, 70 & \multirow{2}{*}{, 733} & \multirow{2}{*}{482} \\
& Uluslararası & 22 & 3,78 &, 61 & & \\
& Toplam & $\mathbf{1 4 6}$ & $\mathbf{3 , 7 8}$ & $\mathbf{6 7}$ & & \\
Dış Öz Güven & Yok & 49 & 3,84 &, 83 & & \\
& Ulusal & 75 & 3,68 &, 69 & \multirow{2}{*}{1,271} & \multirow{2}{*}{284} \\
& Uluslararası & 22 & 3,91 &, 53 & & \\
\hline
\end{tabular}

Tablo 6 incelendiğinde, araştırmaya katılan sporcuların sahip oldukları başarı düzeyi ile öz güven alt boyutları (iç öz güven, dış öz güven) arasinda istatistiksel olarak anlamlı bir fark tespit edilmemiştir $(p>, 05)$. 


\section{Tartışma ve Sonuç}

Araştırmaya katılan sporcuların yaş grupları, beden kütle indeksi grupları, kaybedilen ağırlık yüzde sınıflandırması, yıl içinde kilo düşme sayıları ve başarı düzeyi sınıflandırılmaları ile içsel ve dışsal öz güven düzeyleri arasında istatistiksel açıdan anlamlı farklılık olmadığı sonucuna varılmıştır $(p>, 05)$.

Farklı çalışmalar incelendiğinde; Demirli (2017), elit güreşçilerin müsabaka öncesi ve sonrası durumluluk kaygı düzeylerinin karşılaştırmasına yönelik yaptığı çalışmasında, sporcuların müsabaka öncesi ve müsabaka sonrası durumluk kaygı puan ortalamaları ile yaş değişkeni arasında istatistiksel anlamlı farklılık olmadığını tespit etmiştir. Bu farkın olmayışı sporcuların öz güvenlerinin yeterli oluşuna bağlanmaktadır. Mevcut çalışmada da farkın olmayışı müsabakaya katılan sporcuların öz güvenlerinin yüksek oluşundan ve sporcuların yaşlarının birbirine yakın olmasından kaynaklandığı düşülmektedir.

Bobby ve Semper (1997) yaşları 13 ile 15 arasında olan Meksika kökenli 254 ergen kızla özgüven ile beden imgesi, egzersiz ve beden ağırlı̆̆ arasında bir ilişkiyi incelemeye yönelik yaptıkları çalışmada, özgüven düzeyi, beden imgesi ve egzersiz arasında olumlu bir ilişki olduğu, beden ağırlığı ile özgüven arasında olumsuz bir ilişki olduğunu rapor etmişlerdir. Bu sonuca göre, beden kütle indeksinin yüksek olması ergen kızların öz güven düzeylerinin etkileyebileceğini düşündürmektedir. Mevcut çalışmada istatistiksel farkın olmayışının sporcuların beden kütle indeks değerleri arasındaki farkın yüksek olmamasından kaynaklandığı düşünülmektedir.

Kuson (2014) tarafından yapılan bir başka çalışmada, güreş, boks, taekwondo branşındaki elit düzeydeki sporcuların başarı motivasyonları incelenmiş, güreş sporcularının motivasyon düzeylerinin boks ve taewondo branşındaki sporculara göre daha yüksek olduğu tespit edilmiştir. Bu sonuç, araştırmamızda elde edilen yüksek öz güven düzeylerini destekler niteliktedir.

Araştırma bulgularına göre sporcuların yıl içinde katıldıkları müsabakalarda kilo düşme sayısı azaldıkça öz güven düzeylerinin arttığı görülmektedir. İlgili literatürde bazı çalışmalarda kilo düşmenin hem aerobik hem de anaerobik performansı azalttığı rapor edilmiştir (Fogelhom,1994; 
Fogeholm vd., 1993). Dahası, Franchini vd. (2012), hızlı ağırlık kaybı gerçekleştiren sporcuların, kısa süreli hafıza kaybı, zindelik, konsantrasyon ve benlik saygisının azalmasının yanı sıra öfke, yorgunluk, depresyon ve izolasyon (geri çekilme) gibi durumların artacağını rapor etmiştir. Kilo düşmeyen sporcuların fiziksel ve psikolojik açıdan bu tarz stresörlerle karşılaşmamasından dolayı öz güven düzeylerinin yüksek olabileceği, ağırlık kaybı gerçekleştiren sporcuların ise bu duruma adaptasyon sağladığından kaynaklandığı düşünülebilir.

Sporcuların başarı durumlarına göre öz güven düzeylerinde farklılık olmadığı tespit edilmiştir. Bazı çalışmalar, özgüveni yüksek olan sporcularm yeteneklerini daha iyi sergileyerek ve potansiyellerini daha kolay ortaya koyarak daha iyi müsabaka başarısı elde ettiklerini rapor etmiştir (Ekinci, 2013; Yıldırım, 2013). Ulusal ya da uluslararası herhangi bir başarıya sahip olmayan bireylerin iç öz güvenlerinin daha yüksek olduğu görülmüştür. Bu sonuç, ulusal bir başarıya sahip olmayan güreşçilerin uluslararası arenada yarışamayacağından elit seviyede rakiplerle karşılaşmadığından kaynaklanabilir. Öte yandan, uluslararası başarısı olan katılımcıların dış özgüven düzeylerinin ulusal başarısı olan ve olmayan katılımcılara göre daha yüksek olduğu görülmüştür. Bu durumun kazanılan madalya ve ödüllerin dış öz güveni artırmasından kaynaklanabileceği düşünülmektedir.

Sonuç olarak; elit yıldız greko-romen güreşçilerin içsel ve dışsal öz güven düzeylerinin yüksek olduğu tespit edilmiştir. Bu sonuç, sporcuların müsabaka öncesi ağırlık kaybı gerçekleştirmelerine rağmen öz güven düzeylerinde herhangi bir kayıp olmadığını göstermektedir. 


\title{
EXTENDED ABSTRACT
}

\section{Investigation of Self-Confidence Levels of Elite Cadet Greco-Roman Wrestlers before the Competition According to Various Variables}

*

\author{
İlimdar Yalçın - Cihan Ayhan - Abdullah Düğenci \\ Bingöl University, Sakarya Applied Science Universtiy
}

Self-confidence requires self-esteem. An individual should love himself despite his physical and psychological defects, failures and negativities (Mutluer, 2006). Self-satisfaction is possible only with self-knowledge. A person who knows himself and can improve in accordance with his own principles will be able to raise his own character. When the individual cannot raise his own character and reveal it, he won't be able to establish healthy relationships neither with himself nor with his environment (Cüceloglu, 2003). Self-confidence is one of the most important factors that makes the individual form positive relationships with himself and environment, be a better person and have positive feelings.

Self-confidence has a significant role in many sport branches. For the wrestlers, who do an individual kind of sport, self confidence level is of vital importance. It is thought that variables such as the level of weight loss in a year, achievements gained in competitions and environmental factors affect the level of self-confidence of wrestlers. The athletes who have weight loss has a psychology that competing in lower weight will have a positive contribution to them and the chance of receiving a medal in lower weight is higher. However the studies made in literature about weight loss show that dehydration generally causes a decrease in the physical maximals of the athletes (Maughan and Shirreffs, 2008; Kukidome et al., 2008; Hayes and Morse, 2010, Işık and Cicioğlu, 2016). Once more, there is a change in the hydration state of the athletes who have weight loss, depending on the nutrition and liquid restriction, it is reported that some indications such as sleep disorder, learning, memory, anxiety, depression, hypothermia and muscle dysfunction disorder can be seen (Işık et al., 2013). 
Within the concept of this information, the purpose of this study is to examine the pre-competition self confidence level of the young elite Greco-Roman wrestlers in terms of different variables.

The present study's population was consisted of 288 wrestlers and samples was consisted 146 elite greco-roman wrestlers (age: $16.07 \pm 0.80$, height: $169.61 \pm 9.56$, body weight averages: $69.47 \pm 17.86$, body mass index averages: $23.82 \pm 4.25$ and sports experience: $4.73 \pm 1.67$ ). In addition to the demographic variables, "Self-confidence scale" developed by Akın (2007) was used in the research. The scale consisted of a summary score (general self-confidence) and two subscale (internal and external self-confidence). The normality test of the obtained data was analyzed by the KolmogorovSmirnov test. In the analysis of the obtained data, one-way ANOVA was used for comparisons of more than two variables.

It has been concluded that statistically there is not a significant difference between the age groups, body mass index groups, the classification of lost weight percentage, the number of weight loss within the year and the intrinsic and extrinsic self confidence levels with the success level classifications of the athletes who have taken part in this study $(\mathrm{p}>, 05)$.

When different studies are examined, Demirli (2017) determined in his study made to compare the anxiety level of the elite wrestlers before and after the competition that statistically there is not a significant difference between the anxiety point average of the athletes before/after the competitions and age variables. This absence of difference is attributed to the athletes' adequate self-confidence. It is also considered that the absence of difference in the current study is derived from the high level of self-confidence of the athletes taken part in the competition and the ages of the athletes are close to each other. In their study carried out with 254 adolescent Mexico origin girls aged between 13-15 to analyze the relation between self-confidence and body image, exercise, body weight, Bobby and Semper (1997) reported that there is a positive relation between self confidence level and body image, exercise but a negative relation between self-confidence and body weight. According to this result,it can be thought that high body mass index can affect the self confidence level of the adolescent girls. In the current study, it is thought that the absence of statistic difference is derived from the fact that the difference between the athletes' body mass index and values are not so high. 
In another study carried out by Kuşan ( 2017) success motivations of the elite athletes in wrestling, boxing, taekwondo were examined and it was determined that motivation levels of the wrestlers were higher than the athletes in boxing and taekwondo. This result is such as to support the high level of self confidence levels gained in our study. According to the research findings, it is seen that as the weight loss number of the athletes participated in the competition during the year decreases self confidence levels increase. Some studies in the relevant literature have reported that weight loss decreases both aerobics and anaerobics performance (Fogelhom, 1994; Fogeholm et al., 1993).

It was determined that there was not a difference in the self confidence level according to the success states of the athletes. Some studies reported that athletes with high self-confidence get better competition success by exhibiting their talents better and revealing their potential more easily (Ekinci, 2013; Yıldırım, 2013). It was seen that the individuals who do not have any national or international achievement have a higher internal selfconfidence. This may result from the fact that a wrestler who does not have a national achievement can not compete in the international arena with elite opponents. On the other hand it was detected that participants with an international achievements have a higher external self-confidence when compared with the ones with some and no national achievement. It is thought that this situation may result from the fact that medals and prizes received increase internal self-confidence.

In conclusion, it has been determined that young elite greco-roman wrestlers have high level of intrinsic and extrinsic self-confidence. This result shows that although the athletes have weight loss before the competition, there is no loss in their self confidence level.

\section{Kaynakça / References}

Akın, A. (2007). Öz-Güven ölçeği'nin geliştirilmesi ve psikometrik özellikleri. Abant İzzet Baysal Üniversitesi Eğitim Fakültesi Dergisi, 7 (2), 167-176.

Bobby, G. ve Semper, T. (1997). Body image perception in female mexican american adolescents. Journal of School Health, 67, 112-115. 
Burton K.ve Platts B. (2017). Confidence for dummies. (A. Özkan Çev.). Ankara: Nobel Yaşam Yayıncilık.

Casa, D. J., Armstrong, L. E., Hillman, S. K., Montain, S. J., Reiff, R. V., Rich, B. S. ,..., Stone, J. A. (2000). National Athletic Trainers' Association position statement: fluid replacement for athletes. Journal of Athletic Training, 35(2), 212-224.

Cüceloğlu, D. (2003). İnsan ve davranışı psikolojinin temel kavramlar. (12. Bsm), Remzi Kitabevi, İstanbul.

Çetinkaya, T. (2015). Takım sporlarında sporcu kimliği ve sürekli sportif kendine güven ilişkisi. Doktora tezi, Gazi Üniversitesi, Ankara.

Demirli, A. (2017). Elit güreşçilerin müsabaka öncesi ve sonrası durum kaygl düzeylerinin karşılaştırılması. Yüksek lisans tezi, Bartın Üniversitesi, Bartın.

Ekinci, H. (2013). Müzik öğretmeni adaylarının solo sahne performansına ilişkin özgüven algılarının bazı değişkenler bakımından incelenmesi. Mehmet Akif Ersoy Üniversitesi Eğitim Bilimleri Enstitüsü Dergisi, 2(2), 52-64.

Fogelholm, G. M., Koskinen, R., Laakso, J., Rankinen, T. ve Ruokonen, I. (1993). Gradual and rapid weight loss: Effects on nutrition and performance in male athletes. Med Sci Sports Exerc, 25, 371-377.

Fogelholm, M. (1994). Effects of bodyweight reduction on sports performance. Sports Med, 18, 249-26.

Franchini E., Brito, C. J. ve Artioli, G. G. (2012). Weight loss in combat sports: physiological, psychological and performance effects. Journal of the International Society of Sports Nutrition, 9(1), 52-64.

Göknar, Ö. (2015). Özgüven kazanmak. (5. Bsm), Ankara:Arkadaş Yayınevi. Hayes, L. D. ve Morse, C. I. (2010). The effects of progressive dehydration on strength and power: is there a dose response?, European Journal of Applied Physiology, 108 (4), 701-707.

Isik, O. ve Cicioglu, H. I. (2016). Dehydration, skeletal muscle damage and inflammation before the competitions among the elite wrestlers. Journal of Physical Therapy Science, 28(1), 162-168.

Işık, Ö., Gökdemir, K., Bastık, C., Yıldırım, İ., ve Dogan, İ. (2013). A study on elite wrestlers: Weight loss and depression. Nigde University Journal of Physical Education and Sport Sciences, 7(3), 216-223. 
Kukidome, T., Shirai, K., Kubo, J., Matsushima, Y., Yanagisawa, O., Homma, T. ve Aizawa, K. (2008). MRI evaluation of body composition changes in wrestlers undergoing rapid weight loss. British Journal of Sports Medicine, 42(10), 814-818.

Kusan, O. (2014). Güreş, boks, taekwondo branşındaki elit düzeydeki sporcuların başar motivasyonların çeşitli değişkenlere göre değerlendirilmesi. Yüksek lisans tezi, Gazi Üniversitesi, Ankara.

Maughan, R. J. ve Shirreffs, S. M. (2008). Development of individual hydration strategies for athletes. International Journal of Sport Nutrition and Exercise Metabolism, 18(5), 457-472.

Merey, B. (2010). Yetişkinlerde özgüven duygusu ile anksiyete düzeyi arasındaki ilişkinin karşılaştırılması ve kültürlerarası bir yaklaşım. Yüksek lisans tezi, Maltepe Üniversitesi, İstanbul.

Mutluer, S. (2006). Öz güven oluşmasında manevi değerlerin rolü. Yüksek lisans tezi, Ankara Üniversitesi, Ankara.

Who, E. C. (2004). Appropriate body-mass index for Asian populations and its implications for policy and intervention strategies. Lancet (London, England), 363(9403), 157-163.

Yagmur, R., Isik, O., Kilic, Y. ve Dogan, I. (2019). Weight loss methods and effects on the elite cadet Greco-Roman wrestlers. Journal of Teaching, Research, and Media in Kinesiology, 5, 33-40.

Yıldırım, F. (2013). Sportif sürekli kendine güven alt ölçeğinin uyarlanması ve ortaöğretim kurumlarındaki öğrencilerde sportif sürekli kendine güvenin çeşitli değişkenler açısından incelenmesi. Yüksek lisans tezi, Mersin Üniversitesi, Mersin.

\section{Kaynakça Bilgisi / Citation Information}

Yalçın, İ., Ayhan, C. ve Düğenci, A. (2019). Müsabaka öncesi elit yıldız greko-romen güreşçilerin öz güven düzeylerinin çeşitli değişkenler açısından incelenmesi. OPUS-Uluslararası Toplum Araştırmaları Dergisi, 11(18), 2040-2054. DOI: 10.26466/opus.563554. 